\author{
Paulina Olechowska \\ Julitta Rydlewska \\ Wydział Filologiczny \\ Uniwersytet Szczeciński
}

\title{
EDUKACYJNA I PROMOCYJNA FUNKCJA BBC W ZAKRESIE MEDIA LITERACY
}

\author{
Abstract \\ THE EDUCATIONAL AND PROMOTIONAL ROLE OF THE BBC IN THE FIELD \\ OF MEDIA LITERACY
}

The article proposes a reflection on the experience of British Broadcasting Corporation in promoting media literacy which is defined as "the ability to access, understand and create communications in a variety of contexts". While discussing the issue of media literacy in Poland, one is prompted to refer to the experience of public broadcasters in countries regarded as leaders in pursuing its objectives. The $\mathrm{BBC}$ seems to be a natural choice due to its leading position in the digital revolution of the British media system and its public mission to promote education and reading. The article presents an overview of selected projects committed to the promotion of media literacy among various social groups. The authors seek an answer to the following questions: 1) are these projects in line with the strategy for media literacy formulated by the BBC in 2013? and 2) what conditions would need to be fulfilled if such projects were to be implemented in Poland?

Key words: media literacy, BBC, functions of public media

Dyskusja o potrzebie edukacji medialnej trwa w Polsce od lat i wydaje się nie mieć końca. Przez badaczy wielu dyscyplin naukowych edukacja medialna traktowana jest jako „niedokończony projekt” (będący niejako in statu nascendi), który dotychczas nie wypracował jednolitego programu w zakresie hierarchii celów i zadań. Dowodem konieczności prowadzenia ciągłych debat w zakresie tej dziedziny wiedzy są stałe i żywiołowe zmiany modeli technologicznych i konsumpcyjnych mediów. Potrzebę ustawicznych dyskusji na jej temat dostrzegają coraz to liczniejsze interdyscyplinarne grupy badaczy (czego dowodem są cyklicznie organizowane 
Kongresy Edukacji Medialnej), jak i coraz częstsze podejmowanie zagadnień edukacyjnych zadań mediów przez medioznawców, koncentrujących dotychczas swoje zainteresowania na takich obszarach jak: historia mediów, systemy medialne czy zarządzanie mediami.

W dotychczasowych badaniach dotyczących edukacji medialnej skupiono się na dwóch jej wymiarach: „edukacji o mediach” i „edukacji dla mediów”. O ile postulat "uczenia o mediach" realizują głównie teoretycy i praktycy pedagogiki, a „uczenia dla mediów” - dydaktycy dziennikarstwa, o tyle realizacja wymiaru „uczenia przez media” staje się istotnym dopełnieniem całościowego kształcenia kompetencji medialnych. Dlatego coraz częściej badacze zwracają uwagę na realizację postulatów edukacji medialnej w strategiach i praktyce funkcjonowania polskich mediów, uwzględniając doświadczenia innych krajów - w tym przede wszystkim Wielkiej Brytanii, cieszącej się zasłużoną opinią jednego ze światowych liderów w zakresie edukacji medialnej ${ }^{1}$.

\section{Edukacja medialna a media literacy oraz działania brytyjskiego nadawcy publicznego}

W krajach anglojęzycznych edukacja medialna jest nazywana media literacy (kompetencja medialna), co wynika z silnego powiązania tej stosunkowo młodej dyscypliny naukowej z badaniami kulturowymi (cultural studies) ${ }^{2}$. Jej rozwój w latach 60. ubiegłego wieku jest konsekwencją kontekstowego badania kultury i literatury, ale pozostaje również związany z paternalistyczną fazą rozwoju publicznej działalności misyjnej, która zakładała upowszechnianie wśród społeczeństwa przez elity polityczne, intelektualne i artystyczne, za pomocą mediów, wiedzy (oświecenie publiczne) i wartościowej (wyższej) kultury po to, aby mogło ono uczestniczyć w życiu publicznym ${ }^{3}$.

Pojawiające się $\mathrm{w}$ tytule niniejszego artykułu pojęcie media literacy nie posiada w Wielkiej Brytanii jednolitej definicji. Ofcom, państwowy organ nadzorujący rynek mediów i telekomunikacji, definiuje je jako „zdolność do zdobywania, rozumienia oraz kreowania przekazów medialnych w szerokim kontekście”4.

${ }_{1}$ Por. M. Filiciak, Jaka edukacja medialna? Przykłady spoza Polski, cz. 5, s. 70, https://nowoczesnapolska.org.pl/wp-content/uploads/2012/01/Cyfrowa-Przysz\%C5\%82o\%C5\%9B\%C4\%87-rozdzia\%C5\%82-05.pdf (dostęp: 11.05.2018).

2 A. Ogonowska, Współczesna edukacja medialna: teoria i rzeczywistość, Wydawnictwo Naukowe Uniwersytetu Pedagogicznego, Kraków 2013, s. 23.

3 A. Jaskiernia, Publiczne media elektroniczne w Europie, Wydawnictwo ASPRA-JR, Warszawa 2006 , s. 32.

4 About Media Literacy, www.ofcom.org.uk/research-and-data/media-literacy-research/media-literacy (dostęp: 25.05.2018). 
W zakresie edukacji medialnej w Wielkiej Brytanii aktywnie działają różnego rodzaju instytucje publiczne i środowiska akademickie - w tym także brytyjskie publiczne radio i telewizja, BBC (British Broadcasting Corporation). Jest to naturalną konsekwencją dominującej roli BBC w rewolucji cyfrowej brytyjskiego systemu medialnego ${ }^{5}$, jak i zobowiązania do wypełniania zadań publicznych ( $p$ ublic purposes), wśród których znajduje się postulat promowania edukacji i czytelnictwa ${ }^{6}$. $\mathrm{BBC}$, będąca „największym przedstawicielem mediów publicznych wśród organizacji działających na rzecz promowania media literacy", nie tylko "promuje tematykę edukacji medialnej, ale też tworzy i udostępnia zasoby edukacyjne, a przede wszystkim wyznacza najwyższe światowe standardy wypełniania misji publicznej"8.

Wytyczone działania BBC realizuje dwutorowo: nie tylko tworzy i emituje programy edukacyjne, ale również promuje związane $\mathrm{z}$ edukacją medialną akcje społeczne. Działalność w zakresie edukacji medialnej propaguje nadrzędne hasło tego publicznego nadawcy - uczenie przez media.

W 2010 roku BBC zleciła zewnętrznemu podmiotowi (The Knowledge Agency) zbadanie, w jakim stopniu odbiorcy oceniają skuteczność edukacji medialnej prowadzonej przez BBC przez prezentowane programy i czy nadawca wypełnia swoją publiczną misję w tym zakresie. Materiał badawczy zebrano podczas serii warsztatów zorganizowanych w niewielkich grupach respondentów (łącznie 98 osób) zróżnicowanych pod względem wiekowym, społecznym, środowiskowym i miejsca zamieszkania. Wstępne oceny skuteczności edukacji medialnej i wypełniania misji w zakresie media literacy były dość słabe. Po pierwsze, wielu uczestników nie znało i nie rozumiało pojęcia media literacy, sporo osób nie wiedziało także, że BBC posiada taką misję edukacyjną ani na czym ona polega. Po drugie, uczestnicy nie analizowali wcześniej programów prezentowanych przez BBC pod kątem ich zawartości i celowości przedstawianych treści. Jednakże po wspólnej dyskusji na temat samego pojęcia media literacy oraz zadań wpisanych w misję nadawcy publicznego ilustrowanych przykładami refleksja wzięła górę nad spontanicznością odpowiedzi i ponowna ocena misyjności i skuteczności BBC w zakresie media literacy znacząco wzrosła ${ }^{9}$. Dowodzi to, że rzetelnej ocenie sprzyja świadome uczestnictwo w przekazie medialnym, na co uwagę zwrócili także sami badani.

${ }^{5}$ Por. M. Gruchoła, Edukacja medialna zadaniem mediów publicznych, [w:] P. Bielawski, A. Ostrowski (red.), Media publiczne w Polsce. System medialny w Polsce - pytania i dezyderaty, Wydawnictwo Lena, Wrocław 2010, s. 126.

${ }^{6}$ M. Wielopolska-Szymura, Zadania programowe krajowych rozgłośni BBC jako forma realizacji misji publicznej, „Global Media Journal - Polish Edition” 2010, Spring and Fall, s. 114.

7 J. Jasiewicz, J. Włodarski, Wielka Brytania: szkoła, sektor pozarzadowy i media publiczne, cz. 9, s. 144, https://nowoczesnapolska.org.pl/wp-content/uploads/2012/01/Cyfrowa-Przysz\%C5\%82o\%C5\%9B\%C4\%87-rozdzia\%C5\%82-09.pdf (dostęp: 11.05.2018).

${ }_{8}$ M. Filiciak, Jaka edukacja medialna?..., dz. cyt.

${ }^{9}$ Media Literacy. A Report into Research Conducted on Behalf of the BBC Trust March 2010, http://downloads.bbc.co.uk/bbctrust/assets/files/pdf/review_report_research/ara2009_10/media_ literacy.pdf (dostęp: 25.05.2018). 
Edukacja medialna według BBC to połączenie technicznych umiejętności posługiwania się urządzeniami cyfrowymi (komputer, telefon komórkowy) z kompetencjami pozwalającymi na korzystanie $\mathrm{z}$ nich w sposób świadomy i bezpieczny. Nadawca wyróżnił cztery rodzaje kompetencji. Wykształceni medialnie odbiorcy to tacy, którzy: 1) rozumieją, w jaki sposób powstają programy radiowe i telewizyjne, jak tworzone są strony internetowe, jaki jest związek między przynależnością danego medium do konkretnego wydawcy a doborem i redakcją prezentowanych treści; 2) krytycznie podchodzą do informacji i ich źródeł, potrafią odróżniać zawartość merytoryczną od reklamowej (komercyjnej) i opinie osób od komentarzy nadawcy; 3) zdają sobie sprawę z zasad i regulacji rządzących mediami, z tego, kto je ustala i egzekwuje, są świadomi swojego prawa do składania skarg i zażaleń; 4) w bezpieczny sposób poruszają się w świecie cyfrowym - chronią swoje dane osobowe, umieszczając materiały online czy biorąc bezpośredni udział w programach radiowych i telewizyjnych, potrafią zrozumieć i ocenić informacje dostarczane przez wyszukiwarki, korzystają z płatnych treści dostępnych online ${ }^{10}$.

W 2013 roku BBC opublikowało nową strategię dotyczącą umiejętności korzystania $\mathrm{z}$ medió $\mathrm{w}^{11}$, szczególnie $\mathrm{w}$ kontekście umiejętności czytania i pisania jako dwóch składowych założeń media literacy rozumienia i kreowania przekazów medialnych ${ }^{12}$. Strategia media literacy $\mathrm{BBC}$ ma realizować cztery naczelne cele: 1) współpracę $z$ innymi instytucjami w celu dostarczania jasnych informacji o korzyściach wynikających z nowych technologii i budowania umiejętności cyfrowych; 2) pomoc wszystkim odbiorcom w rozwijaniu umiejętności korzystania z mediów i lepszego zrozumienia środowiska medialnego; 3) pomoc rodzicom i dzieciom w zrozumieniu i zarządzaniu ryzykiem związanym z aktywnością online; 4) zachęcanie odbiorców do twórczego eksperymentowania $\mathrm{z}$ mediami cyfrowymi ${ }^{13}$.

$\mathrm{Na}$ uwagę zasługują trzy istotne - odróżniające tę strategię od tworzonych w Polsce uregulowań w zakresie edukacji medialnej - elementy: 1) szeroko zakrojona współpraca $\mathrm{BBC} z$ różnego rodzaju instytucjami (placówki oświatowe, organizacje pozarządowe i instytucje państwowe) w zakresie realizacji postulatów edukacji medialnej; 2) zwrócenie uwagi na konieczność nabywania kompetencji medialnych przez wszystkich odbiorców mediów, tym samym uwzględniając różne grupy wiekowe i nie pomijając żadnego rodzaju mediów; 3) położenie akcentu na aktywność (twórcze eksperymentowanie), nie zaś pasywność odbiorcy mediów. Wnikliwa analiza strategii BBC $\mathrm{w}$ zakresie media literacy prowadzi ponadto do wniosku, że dokument ten nie wartościuje ani nie selekcjonuje poszczególnych zadań - istotną cechą jest ich komplementarność.

10 Tamże.

11 M. Chapman, New Media Literacy Strategy for the BBC, www.bbc.co.uk/blogs/internet/entries/1755ffe0-4989-3577-9249-bc820cabf3eb (dostęp: 11.05.2018).

12 Tamże.

13 BBC Media Literacy Strategy - May 2013, www.bbc.co.uk/learning/overview/about/assets/ bbc_media_literacy_strategy_may2013.pdf (dostęp: 25.05.2018). 


\section{Przykłady działań edukacyjnych i promocyjnych realizowanych przez BBC}

W swoich działaniach brytyjski nadawca publiczny skupia się na wszystkich aspektach związanych z media literacy, czyli z użytkowaniem, rozumieniem oraz tworzeniem przekazu medialnego. $\mathrm{BBC}$ realizuje zadania w zakresie media literacy dwutorowo: tworzy i emituje programy edukacyjne oraz promuje związane media literacy akcje społeczne.

Przykładem działania długofalowego i zakrojonego na szeroką skalę jest projekt Make It Digital (Zrób to cyfrowo), zainicjowany przez BBC w 2013 roku. Inicjatywy podejmowane w ramach tego projektu niosą przesłanie, że rozwój technologii cyfrowych zmienia i będzie zmieniał życie słuchaczy oraz widzów, zachęcają także zarówno młodsze, jak i starsze pokolenia do kreatywnego i twórczego korzystania $\mathrm{z}$ cyfrowych technologii, do rozwijania podstawowych umiejętności posługiwania się nimi, ale też do zrozumienia, jakie nowe możliwości otwierają. Oferta jest skierowana do szerokiego kręgu odbiorców, przede wszystkim jednak do tych, którzy nie są bezpośrednio zainteresowani światem cyfrowym i nie poszukują samodzielnie związanych z nim treści. Do współpracy zaproszono zespoły wszystkich redakcji, co zaowocowało obecnością treści cyfrowych również $\mathrm{w}$ audycjach i programach, które na co dzień się nimi nie zajmują. Do projektu dołączyli także partnerzy spoza BBC: firmy technologiczne o globalnym zasięgu, cyfrowe start-upy, organizacje pomocy społecznej, lokalne biblioteki. Treści cyfrowe są obecne w programach informacyjnych, edukacyjnych i rozrywkowych na wszystkich platformach BBC (telewizyjnej, radiowej, online). Szacuje się, że w latach 2013-2017 beneficjentami projektu było około 23 milionów ludzi. Jeśli przyjąć, iż każdego tygodnia BBC dociera do $95 \%$ Brytyjczyków ${ }^{14}$, skala odbioru tego projektu nie może dziwić. Jedną z niewątpliwych podstaw sukcesu całego przedsięwzięcia, zarówno wśród odbiorców, jak i partnerów zewnętrznych, jest zaufanie społeczne, jakim cieszy się BBC, profesjonalizm i wysoka jakość produkcji oraz realizowana misja społeczna.

Make It Digital jest projektem, w ramach którego koncentrują się pomniejsze programy edukacyjne, skierowane do różnych grup odbiorców. Uczniowie szkół podstawowych otrzymali zaprojektowany z myślą o jedenastolatkach mikrokomputer osobisty BBC micro:bit. Dzięki niemu dzieci mogą poznawać zasady programowania i ćwiczyć swoje umiejętności na prostych przykładach, czerpiąc przy tym twórczą radość i satysfakcję. Wszyscy uczniowie szkół państwowych, którzy wyrazili takie życzenie, dostali bezpłatnie swój własny egzemplarz. Bardzo ciekawy i cenny edukacyjnie jest zapoczątkowany w 2016 roku projekt zatytułowany Build It Scotland (Zbuduj to w Szkocji). Jego celem jest zachęcanie uczniów szkół

${ }_{14}$ Making It Digital: How the BBC and its Partners Unleashed the UK's Digital Creativity, http:// downloads.bbc.co.uk/learning/makeitdigital/Make_It_Digital_ebook.pdf (dostęp: 23.04.2018). 
podstawowych do wykorzystywania narzędzi 3D do odtwarzania ciekawych obiektów architektonicznych w Szkocji. Oprócz rozwijania umiejętności cyfrowych dzieci mogły uczyć się geografii i topografii Szkocji, poszukiwania i organizowania informacji. $Z$ cyfrowych projektów uczniów stworzono wirtualną mapę Szkocji, z której będą mogły korzystać kolejne pokolenia uczniów. Popularność projektu zaskoczyła samych autorów - wzięło w nim udział około 5000 uczniów z ponad 200 szkockich szkół ${ }^{15}$.

Nadawca zadbał również o to, aby oglądanie telewizji nie było tylko bierną rozrywką. Technobabble (Technobajanie) to cykliczny program telewizyjny skierowany do młodych odbiorców, prezentujący nowości i nowinki technologiczne i umożliwiający widzom tworzenie gier opartych na popularnych serialach telewizyjnych. W programie Doctor Who Game Maker (Doktor Who: Twórca gier), wyemitowanym we wrześniu 2015 roku, dzieci i młodzież nieposiadające szczególnej wiedzy technologicznej i umiejętności za pomocą otrzymanych narzędzi cyfrowych (matryc) podczas telewizyjnego programu tworzyły gry komputerowe inspirowane kultowym serialem science fiction Doktor Who, którymi następnie mogły dzielić się z graczami na całym świecie. Projekt stawiał na kreatywność i zaangażowanie, umiejętności logicznego i cyfrowego myślenia, sekwencjonowania i programowania. Do 2017 roku dzieci zaprojektowały ponad 250 tysięcy gier różnego rodzaju, dodając efekty specjalne czy ożywiając obiekty ${ }^{16}$.

Rozwój technologii cyfrowych oznacza także wzrost zapotrzebowania na wykwalifikowanych pracowników tego sektora i nie chodzi tu tylko o matematyków czy programistów. Zadaniem Make It Digital Quiz (Ankieta dla Zrób to cyfrowo) jest uświadomienie młodzieży, jakie możliwości pracy czekają na nich w sektorze technologii cyfrowych (np. redakcja memów) i jakie oni sami mają predyspozycje. Specjalnie zaprojektowana ankieta online (bazująca na kwestionariuszu oceny zachowania skonstruowanego przez amerykańskiego psychologa Williama Moultona Marstona) profiluje i przypisuje uczestnika do jednego z dziesięciu typów, np. twórcy, analityka, przedsiębiorcy, eksperymentatora. Znając swój typ, nastolatki mogą też dowiedzieć się, w jaki sposób pielęgnować i rozwijać swoje predyspozycje i umiejętności, zobaczyć i posłuchać online innych młodych ludzi, którzy już rozpoczęli karierę zawodową w branżach technologicznej czy cyfrowej i odnieśli w nich sukces. Make It Digital Traineeship (Warsztaty Zrób to cyfrowo) to trwające od sześciu do ośmiu tygodni kursy i warsztaty, na których młodzież może zdobywać podstawowe umiejętności w zakresie technologii informacyjnych.

Jedną z bezsprzecznych wartości projektu Make It Digital jest inkluzyjność - włączanie w krąg potencjalnych beneficjentów jak najszerszych grup społecznych. Cykliczny program telewizyjny Girls Can Code (Dziewczęta potrafią programować) jest szczególnie ważny dla nastoletnich dziewczyn, które często nie mają 
rówieśniczych wzorów, aby zgłębiać nowe technologie tradycyjnie zdominowane przez chłopców. Jest to program typu talent show, w którym dziewczęta mogą zaprezentować swoje umiejętności programowania, stereotypowo zarezerwowane dla chłopców. Najlepszym dowodem na to, że dziewczęta potrafią programować, jest przyznana w 2016 roku nagroda Teen Awards: spośród wszystkich nominowanych laureatkami zostały dwie uczennice. Teen Awards są przyznawane przez projekt Make It Digital i kanał radiowy BBC Radio One młodym ludziom, których cyfrowe umiejętności i osiągnięcia inspirują oraz zmieniają na lepsze życie ich rówieśników. Gala towarzysząca wręczaniu nagrody nie tylko podnosi prestiż zwycięzców w oczach zgromadzonych nastolatków, ale też pokazuje, że zaangażowanie w naukę i nowe technologie może przynieść szeroką rozpoznawalność wśród rówieśników.

Ogromną popularnością, zwłaszcza wśród widzów starszego pokolenia, cieszyła się wyemitowana w 2016 roku seria popularnonaukowych programów telewizyjnych zatytułowana Big Life Fix, pokazująca projektantów i ich niezwykłe produkty przełamujące specyficzne bariery w codziennym funkcjonowaniu, jak na przykład długopis dla osoby cierpiącej na chorobę Parkinsona. W 2017 roku widzowie mieli okazję obejrzeć kilka filmów dokumentalnych, w których projektanci opowiadali między innymi o stosowaniu narzędzi cyfrowych w swojej pracy. Wykorzystując zamiłowanie Brytyjczyków do rozmów o pogodzie, w 2016 roku zainicjowano Weather Watchers (Strażnicy pogody), adresowany głównie do starszego pokolenia i wciąż niezmiernie popularny swoisty klub online skupiający rzesze „strażników pogody" - mieszkańców różnych części Zjednoczonego Królestwa, którzy dzielą się bieżącymi obserwacjami meteorologicznymi i na platformie internetowej BBC umieszczają zdjęcia oraz dane dotyczące pogody w swojej okolicy, wykorzystywane później w serwisach pogodowych BBC, zarówno tych lokalnych, jak i o zasięgu ogólnokrajowym. Ogromna popularność Weather Watchers skłoniła BBC do wydania przewodnika (w wersji drukowanej oraz online) objaśniającego, jak zostać jednym z nich i w jaki sposób umieszczać swoje materiały na platformie cyfrowej, jak korzystać z poczty i wyszukiwarek. Od samego początku z akcją współpracują lokalne biblioteki - to one pokazały początkującym użytkownikom, jak korzystać z komputera i jak rozwijać swoje cyfrowe umiejętności. Dzięki Weather Watchers wiele starszych osób mogło przezwyciężyć swój strach przed komputerem i Internetem i przekonać się, że dzięki nim mogą miło spędzać czas i rozwijać swoje zainteresowania.

Niewątpliwą edukacyjną wartością projektu Make It Digital jest budowanie świadomości znaczenia i potencjału technologii oraz narzędzi cyfrowych, pokazanie, jak mocno łączą się z różnymi sferami codziennego życia, a także doskonalenie umiejętności zarówno cyfrowych, jak i tradycyjnych, takich jak pozyskiwanie i krytyczne przetwarzanie informacji czy praca w zespole. Połączenie wartości edukacyjnych z przystępnym językiem i wzbogaceniem przekazu o elementy zabawy i rozrywki sprawia, że Make It Digital jest świetnym przykładem projektu, który 
bawiąc, uczy i ucząc, bawi, wpisując się tym samym w misję społeczną BBC jako nadawcy publicznego.

$\mathrm{Na}$ tle różnych instytucji zajmujących się edukacją medialną BBC wyróżnia się tym, że kieruje wiele swoich działań do osób starszych. Przykładem może być akcja promocyjna First Click ${ }^{17}$ skierowana do osób powyżej 55. roku życia. W ramach akcji emitowane są programy telewizyjne i radiowe promujące zalety Internetu oraz organizowane są szkolenia i kursy w lokalnych społecznościach. Kolejnym przykładem kampanii wspierającej umiejętności cyfrowe wśród osób starszych jest akcja Give An Hour ${ }^{18}$ (Podaruj godzinę), której zadaniem jest promocja idei poświęcenia jednej godziny na dzielenie się ze znajomymi i bliskimi praktycznymi umiejętnościami korzystania $\mathrm{z}$ Internetu ${ }^{19}$.

Z zaprezentowanego opisu wynika, że w ostatnich latach działalność BBC koncentruje się na pomaganiu ludziom w rozwijaniu umiejętności „dostępu”, w szczególności tym, którzy stykają się z Internetem po raz pierwszy. Przykładem są promowane przez BBC rządowe moduły szkoleniowe (www.myguide.gov.uk) Get Connected (Połącz się), które można odbyć w bibliotekach lub dzięki infolinii. Ich zadaniem jest nauka podstawowych umiejętności korzystania z komputera (obsługa klawiatury i myszy, wysyłanie wiadomości e-mail, wyszukiwanie informacji, bezpieczeństwo w Internecie) ${ }^{20}$.

Realizowane przez BBC działania w zakresie promocji edukacji medialnej realizują dwa modele: zagrożenia - polegający na działaniach profilaktycznych, mających zapobiec negatywnym skutkom oddziaływania mediów (np. Get Connected), oraz model pozytywny - wskazujący na korzyści płynące $\mathrm{z}$ ich użytkowania (np. Teen Awards), rozwijając elementy własnej twórczości czy hobby (np. Weather Watchers $)^{21}$.

\section{Podsumowanie}

Przez swoją działalność w zakresie media literacy BBC realizuje nadrzędne hasła związane z edukacją medialną, która polega na uczeniu o mediach/przez media/dla mediów, stając się podmiotem w istotny sposób dopełniającym całościowy program

17 Zob. www.bbc.co.uk/firstclick (dostęp: 11.05.2018).

${ }_{18}$ Zob. www.bbc.com/news/uk-england-15429097 (dostęp: 12.05.2018).

19 Por. J. Braun, M. Barnatt-Reszczyński, Edukacja medialna - rola telewizji publicznej, [w:] M. Federowicz, S. Ratajski (red.), O potrzebie edukacji medialnej w Polsce, Polski Komitet do spraw UNESCO, Krajowa Rada Radiofonii i Telewizji, Warszawa 2015, s. 412.

${ }^{20}$ Get Connected. Your Easy Guide to Getting Started Online, BBC Radio 2, http://downloads. bbc.co.uk/radio2/getconnected/r2learning_final.pdf (dostęp: 24.05.2018).

${ }^{21}$ P. Drzewiecki, Edukacja medialna w Polsce w latach 2008-2011. Najważniejsze inicjatywy, główne problemy, perspektywa rozwoju, s. 70-71, https://kometa.edu.pl/uploads/publication/202/015f_ A108.pdf?v2.4 (dostęp: 28.05.2018). 
kształcenia kompetencji medialnych. Tym samym dzięki powołanemu w 2003 roku Ofcomowi, który nadzoruje prace badawcze w dziedzinie edukacji medialnej (czego przykładem są na bieżąco realizowane i monitorowane badania w zakresie brytyjskiej media literacy ${ }^{22}$ ), jak i za sprawą realizowanych przez BBC jakościowych badań odbioru przekazów związanych z inicjatywami edukacji medialnej23 $\mathrm{BBC}$ dotrzymuje kroku żywiołowym zmianom modeli technologicznych i konsumpcyjnych mediów. Posiada tym samym dodatkowe narzędzia, dzięki którym może dostosować swoją ofertę do aktualnego zapotrzebowania odbiorców, uwzględniając istotne - z punktu widzenia prowadzonych działan - parametry: wiek odbiorcy, rodzaj użytkowanego medium oraz posiadane kompetencje/umiejętności medialne.

$\mathrm{Z}$ punktu widzenia zarządzania mediami nie bez znaczenia jest fakt, że tworzone przez $\mathrm{BBC}$ projekty promocyjne w zakresie media literacy mają na celu również realizowanie postulatu autopromocji. Uwzględnienie w projektach umiejętności rozumienia i kreowania ma decydujące znaczenie dla korzystania z usług brytyjskiego nadawcy, tak jak i tworzenie przez odbiorców BBC treści, które są udostępniane $\mathrm{w}$ mobilnych aplikacjach internetowych. $\mathrm{W}$ strategii $\mathrm{BBC}$ media literacy z 2013 roku czytamy: „Widzowie muszą także rozwijać umiejętności i pewność cyfrową, aby w pełni korzystać z nowych technologii, takich jak usługi IP typu Connected TV i produkty BBC Online, takie jak News, Sport i iPlayer, które są coraz częściej wyświetlane na czterech ekranach - na komputerze stacjonarnym i laptopie, tablecie, smartfonie i podłączonym telewizorze" 24 .

Czy przedstawione studia przypadków można byłoby przeszczepić na polski grunt? Bez wątpienia tak. Z pewnością opisane projekty wzbudziłyby zainteresowanie wśród radiosłuchaczy i telewidzów polskiego nadawcy publicznego. Pojawiają się trzy nurtujące pytania:

Czy instytucje publiczne, $w$ tym przede wszystkim zarządzający polskimi mediami publicznymi, są faktycznie zainteresowani krzewieniem edukacji medialnej, w tym choćby nauczania w zakresie rzetelności przekazu? ${ }^{25}$ Czy może jednak wolą cieszyć się instytucjonalną przewagą wiedzy i kompetencji o mediach, nie doskonaląc swoich odbiorców w tym zakresie? (W nakreślonych przez BBC Trust ${ }^{26}$ zadaniach brytyjskiego nadawcy publicznego w zakresie interesu społeczeństwa

${ }^{22}$ Links to External Media Literacy Resources, www.ofcom.org.uk/research-and-data/media-literacy-research/links (dostęp: 25.05.2018).

${ }^{23}$ Por. Media Literacy - Language \& Branding Qualitative Research, BBC Audiences North \& Optimisa Research, November 2013, s. 5, www.bbc.co.uk/learning/overview/about/assets/bbc media_literacy_unified_language_research_2014.pdf (dostęp: 12.05.2018).

${ }^{24}$ BBC Media Literacy Strategy..., dz. cyt.

25 Por. P. Boroń, Edukacja medialna w Polsce XXI wieku ze szczególnym uwzględnieniem prac KRRiT w latach 2007-2010, www.ktime.up.krakow.pl/ref2010/boron.pdf (dostęp: 21.05.2018).

${ }^{26}$ BBC Trust - w latach 2007-2017 był niezależnym organem zarządzającym BBC, jego zadaniem było podejmowanie decyzji w interesie płatników opłat abonamentowych, w 2018 roku jego funkcje przejął Ofcom. 
obywatelskiego napisano: „BBC powinno pomóc ludziom stać się znawcami mediów"27).

Jakie jest organizacyjne umocowanie w strukturze polskiego nadawcy publicznego redakcji edukacyjnych? Redakcja Projektów Edukacyjnych jest składową programu TVP ABC - antenę tę trudno uznać za typowy projekt misyjny. Powstały w 2013 roku we współpracy z Ministerstwem Edukacji Narodowej, w partnerstwie z innymi instytucjami (m.in. Cyfrową Szkołą, Muzykoteką Szkolną, Ninateką, Fundacją Nowoczesna Polska, Scholaris i Centrum Fizyki Teoretycznej ${ }^{28}$ ) dobrze zapowiadający się Portal Edukacyjny Telewizji Polskiej (https://edu.tvp.pl/) nie jest kontynuowany (ostatnie aktualizacje pochodzą z 2014 roku) ${ }^{29}$.

Czy słabe i niedofinansowane polskie media publiczne są $\mathrm{w}$ stanie skutecznie promować i realizować projekty w zakresie edukacji medialnej? (W latach 2010-2017 łączny udział telewizji publicznej w rynku telewizyjnym spadł o prawie $12 \%^{30}$; reklama stanowi prawie $70 \%$ budżetu TVP, co plasuje Polskę na ostatnim miejscu wśród europejskich nadawców publicznych pod względem struktury przychodów $\left.{ }^{31}\right)$. Stawiamy tezę, że bez formalnego i celowego wsparcia przez organy państwowe (głównie Ministerstwo Edukacji Narodowej) oraz partnerstwa $\mathrm{z}$ instytucjami odpowiedzialnymi za realizację postulatów edukacji medialnej media publiczne wciąż będą jedynie doraźnie wspomagać ten obszar kompetencji komunikacyjnych, tym samym nie dotrzymując kroku żywiołowym zmianom modeli technologicznych i konsumpcyjnych mediów ${ }^{32}$.

\section{Bibliografia}

Abonament rtv w Europie, sierpień 2013, https://s.tvp.pl/repository/attachment/e/8/f/e8fce5f0f f267f5017db768198b0cf7c1393496841119.pdf.

About Media Literacy, www.ofcom.org.uk/research-and-data/media-literacy-research/media-literacy.

BBC Media Literacy Strategy - May 2013, www.bbc.co.uk/learning/overview/about/assets/ bbc_media_literacy_strategy_may2013.pdf.

27 Public Purposes: Sustaining Citizenship and Civil Society, www.bbc.co.uk/aboutthebbc/insidethebbc/whoweare/publicpurposes/citizenship.html (dostęp: 25.05.2018).

${ }_{28}$ dmilo, pszl, Tysiąc odcinków na www.edu.tvp.pl, www.tvp.info/12243607/tysiac-odcinkow-na-wwwedutvppl (dostęp: 30.05.2018).

${ }^{29}$ Zob. https://edu.tvp.pl/ (dostęp: 30.05.2018).

${ }^{30}$ J. Reisner, Rynek telewizyjny w 2017 roku, Warszawa 2018, s. 9, www.krrit.gov.pl/Data/Files/_public/Portals/0/kontrola/program/tv/problemowe/rynek-telewizyjny-w-2017.pdf (dostęp: 12.05.2018).

${ }_{31}$ Abonament rtv w Europie, sierpień 2013, s. 4, https://s.tvp.pl/repository/attachment/e/8/f/e8fce5f0ff267f5017db768198b0cf7c1393496841119.pdf (dostęp: 12.05.2018).

${ }^{32}$ Część zaprezentowanych w artykule opisów i wniosków ukazała się w artykule: P. Olechowska, J. Rydlewska, Zrób to cyfrowo, „Refleksje. Zachodniopomorski Dwumiesięcznik Oświatowy” 2018, nr 4, s. 36-39. 
Boroń P., Edukacja medialna w Polsce XXI wieku ze szczególnym uwzględnieniem prac KRRiT w latach 2007-2010, www.ktime.up.krakow.pl/ref2010/boron.pdf.

Braun J., Barnatt-Reszczyński M., Edukacja medialna - rola telewizji publicznej, [w:] M. Federowicz, S. Ratajski (red.), O potrzebie edukacji medialnej w Polsce, Polski Komitet do spraw UNESCO, Krajowa Rada Radiofonii i Telewizji, Warszawa 2015.

Chapman M., New Media Literacy Strategy for the BBC, www.bbc.co.uk/blogs/internet/entries/1755ffe0-4989-3577-9249-bc820cabf3eb.

dmilo, pszl, Tysiąc odcinków na www.edu.tvp.pl, www.tvp.info/12243607/tysiac-odcinkow-na-wwwedutvppl.

Drzewiecki P., Edukacja medialna w Polsce w latach 2008-2011. Najważniejsze inicjatywy, główne problemy, perspektywa rozwoju, https://kometa.edu.pl/uploads/publication/202/015f_ A108.pdf?v2.4.

Filiciak M., Jaka edukacja medialna? Przykłady spoza Polski, cz. 5, https://nowoczesnapolska.org.pl/wp-content/uploads/2012/01/Cyfrowa-Przysz\%C5\%82o\%C5\%9B\%C4\%87-rozdzia\%C5\%82-05.pdf.

Get Connected. Your Easy Guide to Getting Started Online BBC Radio 2, http://downloads.bbc. co.uk/radio2/getconnected/r2learning_final.pdf.

Gruchoła M., Edukacja medialna zadaniem mediów publicznych, [w:] P. Bielawski, A. Ostrowski (red.), Media publiczne w Polsce. System medialny w Polsce - pytania i dezyderaty, Wydawnictwo Lena, Wrocław 2010.

https://edu.tvp.pl/

Jasiewicz J., Włodarski J., Wielka Brytania: szkoła, sektor pozarządowy $i$ media publiczne, cz. 9, https://nowoczesnapolska.org.pl/wp-content/uploads/2012/01/Cyfrowa-Przysz\%C5\%82o\%C5\%9B\%C4\%87-rozdzia\%C5\%82-09.pdf.

Jaskiernia A., Publiczne media elektroniczne w Europie, Wydawnictwo ASPRA-JR, Warszawa 2006.

Links to External Media Literacy Resources, www.ofcom.org.uk/research-and-data/media-literacy-research/links.

Making It Digital: How the BBC and its Partners Unleashed the UK's Digital Creativity, http:// downloads.bbc.co.uk/learning/makeitdigital/Make_It_Digital_ebook.pdf.

Media Literacy - Language \& Branding Qualitative Research, BBC Audiences North \& Optimisa Research, November 2013, www.bbc.co.uk/learning/overview/about/assets/bbc_media_literacy_unified_language_research_2014.pdf.

Media Literacy. A Report into Research Conducted on behalf of the BBC Trust March 2010, http:// downloads.bbc.co.uk/bbctrust/assets/files/pdf/review_report_research/ara2009_10/media_literacy.pdf.

Ogonowska A., Współczesna edukacja medialna: teoria i rzeczywistość, Wydawnictwo Naukowe Uniwersytetu Pedagogicznego, Kraków 2013.

Olechowska P., Rydlewska J., Zrób to cyfrowo, „Refleksje. Zachodniopomorski Dwumiesięcznik Oświatowy" 2018, nr 4, s. 36-39.

Public Purposes: Sustaining Citizenship and Civil Society, www.bbc.co.uk/aboutthebbc/insidethebbc/whoweare/publicpurposes/citizenship.html.

Reisner J., Rynek telewizyjny w 2017 roku, Warszawa 2018, www.krrit.gov.pl/Data/Files/_public/Portals/0/kontrola/program/tv/problemowe/rynek-telewizyjny-w-2017.pdf.

Wielopolska-Szymura M., Zadania programowe krajowych rozgłośni BBC jako forma realizacji misji publicznej, „Global Media Journal - Polish Edition” 2010, Spring and Fall.

www.bbc.co.uk/firstclick.

www.bbc.com/news/uk-england-15429097. 